\title{
THE INQUISITORIAL FUNCTIONS OF GRAND JURIES
}

\author{
GEORGE H. DESSION AND ISADORE H. COFENं
}

WHILE denying the traditional virtues of grand juries and discrediting them as wielders of the power of indictment, current criticism nevertheless remains non-committal as to their value for John Doe investigation into crime. As epitomized by the report of the National Commission for Law Observance and Enforcement, there seems to be some feeling that they are still of possible use in that quarter: "Today the grand jury is useful only as a general investigating body for inquiring into the conduct of public officers and in case of large conspiracies. It should be retained as an occasional instrument for such purposes. ..." 1 In the same vein, legislation in the information states, mirrored in the American Law Institute's Draft Code of Criminal Procedure, retains the possibility of impanelling occasional grand juries for purposes of investigation.?

But with attention concentrated on the disadvantages of accusation by indictment, the implications of provision for merely occasional grand juries have perhaps not been entirely foreseen. For these two problems-accusation and investigation-are scarcely separable, either in practice or policy. Grand jury inquiry has by no means been confined to city-wide inquiries into "the conduct of public officers," nor again to dealing with "large conspiracies." Criminal investigation has also its everyday side. Not infrequently witnesses must be subpoenaed, i.c., there must be an investigation, before it is possible to determine on a charge against some particular person, whether complaint before a magistrate or information by the prosecutor be the step contemplated. The extent of past reliance on grand juries in this regard is well brought out in a minority opinion by Judge Chase of the New York Court of Appeals:

"In many counties of the state grand juries meet at very infrequent intervals, and when evidence that a crime has been

\footnotetext{
*Instructor in the Yale School of Law; Managing Editor of the YALS LAW JOURNAI, 1929-30.

$\div$ Member of the third year class in the Yale School of Law.

1 Report on Prosecution of the National Comimssion for laiw OBSERVANCE AND ENFORCEMIENT (1931) 37.

2 Code of Crrumnal Procedure, Tentative Draft No. 1 (Am. I. Inst. 1928) c. 4. \$ 119 , provides that a grand jury shall be summoned at least once a year in each county.
} 
committed is clear, but the person committing the crime cannot be ascertained without taking the depositions of witnesses, the delay in waiting for a grand jury to meet may result in a failure of justice. It should not necessarily be fatal to an information [laid before a magistrate] if it does not name or designate the person who committed the crime." 3

Failing the automatic impanelling of grand juries at frequent regular intervals, the suggested need for relaxing the requirements of complaints before magistrates becomes practically imperative, unless the alternative of entrusting subpoena power to the prosecutor be adopted. 4 But this means empowering magistrates and prosecutors to conduct general investigations and even "fishing expeditions," a possibility conventionally held dangerous in the extreme.5 If the institution of such inquisitorial "one man grand juries" is inevitably to accompany a system of accusation by information, argument for the latter should support also the former.

These two problems, moreover, unfortunately dealt with as separable, present important issues of policy in common. It is urged that grand jury participation in the process of accusation amounts to a mere rubber-stamping by bystanding jurors, serving but to dissipate responsibility preferably shouldered entire by the prosecutor. ${ }^{6}$ How shall one then picture the role of these same jurors in a general investigation? Has the latter process some tendency to stir independent initiative on the part of the jurors, whilst curbing it on the part of the prosecutor? It will

${ }^{3}$ People ex rel. Livingston v. Wyatt, 186 N. Y. 383, 395, 79 N. E. 330, 335 (1906).

4 It is, of course, still legally possible to impanel a grand jury whonover needed in an information state. In Missouri they were continued in almost constant session in the large cities, being used as "deposition mills" by the prosecution, and also for investigating purposes. Extracts from Corrospondence with Arthur V. Lashly (1927). 5 THe PANer 3; Cockrell, Mandltory Grand Juries in Missouri (1931) 9 THE PANED 47. They are also still extensively used in Indiana and Iowa. Morse, $A$ Survey of the Grand Jury System (1931) 10 ORE. L. REv. 295, 342.

More generally, however, they have fallen into disuse. This has been the experience of Connecticut, Michigan, Nebraska, Washington and Wisconsin. Ibid. 223 n. 116; Nahum and Schatz, The Grand Jury In Connooliout (1931) 5 CoNN. BAR. J. 111, 124.

A recent Michigan law has provided for the regular impanelling of grand juries to sit for six months terms. Pub. Acts 1931, No. 284. See Toy, Miohigan's New Law for Sis; Months Grand Juries (1932) 10 THe PANEL 3.

- Consult People ex rel. Livingston v. Wyatt, supra noto 3, at 391, 79 N. E. at 333.

- Miller, Informations or Indictments in Criminal Cases (1024) 8 MiNN. L. REv. 379; Moley, The Initiation of Criminal Prosecutions by Indictmont or Information (1931) 29 MrCH. L. Rev. 403; Morse, op. cit. supra noto 4 , at 362; REPORT cit. supra note 1 , at 36,124 . 
be recalled that the relations between prosecutor and jury in each of these processes are assuredly of a legal identity.? If the interests of justice will be better served by stripping away the prosecutor's grand jury mask-or, from another point of view, his grand jury check-in the one case, why not then in the other? Proposals such as that quoted from the Wickersham Report, with the issue raised by inquisitorial magistrates and prosecutors, suggest an examination of the place occupied by grand juries in our inquisitorial scheme. The various types of agencies entrusted with inquisitorial power will first be reviewed, after which the conditions and limitations on its exercise by each may be considered.

\section{I}

The proceedings to be reviewed are of considerable variety, ranging from those concerned with but a single occurrence, like an unsolved murder, to those comprehending a whole widespread system of graft and corruption. An investigation may be $e x$ parte or otherwise, with hearings conducted secretly or in public. The prime purpose may be prosecution of particular culprits, or exposure of a general condition. But all are characterized by the exercise of a power termed inquisitorial. What are the requisites of this power, and the conditions of its effectiveness, by which grand juries and other investigating bodies may be contrasted and evaluated?

\section{Agencies Empowered to Inquire Generally Into Crime}

"The proceedings before a grand jury constitute the only general criminal investigation known to the law." So argued the New York court, holding invalid an investigation which the attorney general attempted to conduct into the suspected murder of one Clarence Peters. ${ }^{8}$ The sense in which this familiar statement must be taken and the requisites of inquisitorial power may best be understood by setting up the limitations traditionally imposed on inquiry by magistrates and prosecutors as a background. A prosecutor may indeed inquire generally, but, in the majority of our jurisdictions, without subpoena power. The ask-to-see summons, while persuasive, is by no means the same thing. Magistrates, on the other hand, while empowered to issue subpoenas, are bound in their investigations by the confines of a specific charge.

The nature of this charge will bear scruting at this point,

7 Consult Part $\Pi$, infra, for a discussion of these relations.

8 Ward Baking Co. v. Western Union Tel. Co., 205 App. Div. 723, 728, 200 N. Y. Supp. 865,869 (3d Dep't 1923). 
however, for the slightest relaxation in its requirements amounts to authorization for a "one man grand jury," i.e., a magistrate with general inquisitorial powers. A typical provision governing the requirements of the complaint or information which serves to confer jurisdiction on a magistrate, is Section 148 of the New York Code of Criminal Procedure:

"When an information is laid before a magistrate, of the commission of a crime, he must examine on oath the informant or prosecutor, and any witnesses he may produce, and take their depositions in writing, and cause them to be subscribed by the parties making them." 9

Under these and similar provisions in the majority of states, ${ }^{10}$ the questions upon which the possibility of conducting a general investigation before a magistrate must depend are, first, may the information be purely upon information and belief; and second, may it fail to specify any particular offender?

Were the answer to either question in the affirmative, it would be possible to conduct a "fishing expedition" or John Doe investigation. But the New York Court has held insufficient a complaint which does not state the sources of information and grounds of belief in a fashion to "fairly warrant the inference by the magistrate that in good faith and on reasonable grounds the complainant believes that a definite crime has been committed by a designated person." 11 Such statutes are similarly construed in other jurisdictions. ${ }^{12}$ The complaint is required to designate some person "named or described." From time to time a magistrate has taken it upon himself to conduct an investigation upon a complaint against "John Doe", no particular person being referred to, but where the proceeding has been contested the appellate courts have always held it to be without jurisdiction..$^{13}$

${ }^{9}$ Gilbert's Criminal Code and Penal LaW (1930) 101.

10 Constitutional and statutory provisions are summarized in tho Commentaries on Code of Criminal Procendre (Am. L. Inst. 1928) c. 1, \$1.

11 People ex rel. Livingston v. Wyatt, supra note 3.

22 Note (1908) 9 Ann. Cas. 977.

${ }^{13}$ People ex rel. Sampson v. Dunning, 113 App. Div. 35, 98 N. X. Supp. 1067 (2d Dep't 1906) ; Matter of Both, 200 App. Div. 423, 102 N. X. Supp. 822 (2d Dep't 1922); People ex rel. Travis v. Knott, 204 App. Div. 370, 198 N. Y. Supp. 142 (1st Dep't 1923) ; see Medalie, Grand Jury Invcstigations (1929) 7 The Paned 5.

It has been said that any judge of a court of record in Now York may now conduct the inquiry commonly known as a John Doo proceeding, for the purpose of ascertaining whether there is sufficient evidence to warrant submission of the matter to a grand jury. Tuttle, The Grand Jury Systcm (1927) 5 The Panex 2, 3. The proceedings contemplated may be tho typo of Joln Doe complaint before a magistrate, wherein a particular porson of name unknown is intended to be designated, and is described as accus 
By the foregoing limitations the essentials of inquisitorial power are suggested. Preceding the stage where specific accusations are desired or supportable, investigation must be free from any restraint comparable to the specific charge and showing of probable cause, required to confer jurisdiction and restricting the scope of inquiry before a magistrate. Since the objectiveto establish the occurrence of a suspected criminal transaction, or the implication therein of a particular suspect-is apt to depend on the compelling of testimony and production of evidence by unwilling witnesses, there must be the power, laching in the types of inquiry conducted by detectives or in the prosecutor's office, to issue subpoenas and to punish for contempt.

The very requisites of this power render it peculiarly susceptible of abuse. "Fishing expeditions" may be launched, without probable cause to justify the attendant casting of suspicions and besmirching of reputations. Where persons ultimately to be prosecuted are known from the outset, a proceeding as yet formally aimed at no one may permit their being subpoenaed as witnesses, thereby evading-or avoiding-any privilege of "parties" against being called at all. An inquiry ostensibly into crime may cloak the securing of evidence for private litigation. Orders to produce documentary evidence in quantity may work unnecessary inconvenience, in the matters of time and expense. But the power must nevertheless be lodged somemhere. For purposes of investigating into crime generally, the traditional solution has been to entrust it to grand juries, while denying it to other agencies in the criminal process. Hence the conception of grand juries as the only general inquisitorial bodies known to our law, and identification of the power with proceedings before them.

In a number of states, however, this traditionally grand jury power has now been definitely lodged elsewhere. Objections on constitutional grounds-for the most part along separation-ofpowers lines-have been unavailing. ${ }^{14}$ Connecticut offers the oldest example, power to conduct a John Doc inquisition into

rately as possible. Or it might be argued that from the power of a judge of a court of record to impanel a grand jury when, in his discretion, the public interest may so require, a power to subpoena witnesses in aid of his discretion may be implied. But the few cases on this point-both in other states-are squarely against the inference. Williams v. Pcople, 10: Colo. 1909, 103 Pac. 298 (1909); Ketcham v. Comm., 204 Ky. 168, 203 S. W. 725 (1924).

14 State v. Daniels, 38 S. D. 81, 160 N. W. 723 (1916); Matter of Clarl;, 65 Conn. 17, 31 Atl. 522 (1894); MicCarthy v. Clancy, 110 Conn. 482, 148 Atl. 551 (1931); see People v. Doe, 226 Mich. 5, 196 N. W. 757 (1921) (divided court; four judges held the statute valid, and four avoided passing on the issue); MIarsh, Michigan's One MIan Grand Jury (1924) $8 \mathrm{~J}$. AMr. JUD. Soc. 121. 
crime being lodged originally in bodies of three grand jurors, and more recently, also in bodies of three justices of the peace. ${ }^{15}$ In Michigan and a few other states more recent authorization by statute is found for similar inquiries by single magistrates or judges, referred to as the "one man grand juries." 10 In Kansas, Montana and Utah, statutes authorize similar inquiries by prosecuting attornies into gambling or liquor offenses. ${ }^{27}$

The powers of United States Commissioners to subpoena witnesses in proceedings following the filing of a complaint are implied from the provision that they may arrest, imprison, or bail an offender "agreeably to the usual mode of process agninst offenders in such state." ${ }^{18}$ In a state where the magistrates may not conduct general investigations the United States Commissioner would consequently be similarly unauthorized. ${ }^{10}$ But in the few states where magistrates have been empowered to act as "one man grand juries," it may well be that the United States Commissioners are similarly authorized. ${ }^{20}$

\section{Agencies for Special Types of Investigation}

In 1926 the New York Court of Appeals, in the course of upholding a statute authorizing the attorney general to investigate and to subpoena and examine witnesses with a view to discovering violations of the local Blue Sky law, took occasion to point out that the investing of officials and bodies other than grand juries with inquisitorial power was by no means unusual; that "the power here attacked is akin to that right of the legislature to investigate and subpoena and examine witnesses to the end of safeguarding public interests by appropriate legislation and which is so well established as to have passed beyond the realm of controversy." ${ }^{21}$ As examples of analogous statutes conferring power to investigate on administrative boards and officials,

15 ConN. Gen. Stat. (1930) § 366.

${ }^{16}$ MICH. CoMp. LawS (1929) \& 17217; S. D. Comp. Laws (1929) § 4504; VT. Gen. Laws (1917) § 6617, as amended by Pub. Acts 1921, No. 207.

17 KaN. Rev. Stat. ANN. (1923) c. $62, \S 301$ (gambling, liquor or any offense where the accused is a fugitive from justice); MONT. Rev. Codns (Choate, 1921) § 11109 (liquor); UTAH Comp. Laws (1917) § 3374 (liquor).

Statutes conferring power on the attorneys general to inquiro into offenses against anti-trust, blue sky and election laws are also familinr. For example: N. Y. GEN. BuS. LAW (1921) § 352; N. Y. ExEc. LAW (1022) § 66-A; Kan. Rev. Stat. ANN. (1923) c. 50, § 153.

${ }^{18}$ REv. STAT. $\$ 1014$ (1875), 18 U. S. C. $\$ 591$ (1926).

10 See Matter of Pacific Tel. \& Tel. Co., 38 F. (2d) 833 (N. D. Calif, 1930). The court held that the United States Commissioner in California was unauthorized to subpoena witnesses and compel the production of ovidence to establish probable cause for the issuance of a search warrant.

${ }^{20}$ See ibid. 835.

${ }^{21}$ Dunham v. Ottinger, 243 N. Y. 423, 434, 154 N. E. 298, 301 (1926). 
the Court pointed to those concerning the Superintendent of Banks, the Commissioner of Agriculture and the Commissionerof Accounts of the City of New York. New York is, moreover, still a state where grand juries are continually and extensively employed.

Without attempting to enumerate every statutory investment of a body other than a grand jury with inquisitorial power which may be turned to the exposure of crime-in New York State alone they number well over twenty-a review of a number of instances will serve to illustrate the manner in which some of these supplement the grand juries. ${ }^{22}$ The burden of investigation into the criminal activities of vice squad stool pigeons in $\mathrm{New}$ York was recently borne not by a grand jury, but by the Appellate Division of the Supreme Court. Inquiry into the "Queens sewer scandal" a few years ago was conducted first by Judge Scudder, and then by Judge Shearn, each acting as a IIoreland Act Commissioner, by direction of the governor, assisted by eminent counsel and a corps of legal and technical assistants and investigators. This inquiry resulted in the conviction of the former borough president. Under the Public Officers Law in New York the head of a state department, armed with the power of subpoena, may make full investigation as to the official conduct of any subordinate. The Public Service Commission and Transit Commission are given powers of wide scope for investigating into matters relating to public utilities. Miost important of all, are the investigatory powers of the legislatures. ${ }^{23}$ They may compel the attendance of witnesses and the production of books, papers and records, before a legislative committee of inquiry, as in the Lexow, Hughes or Armstrong, and Hofstadter investigations. The investigation of the Police Department during the Gaynor administration in New York, by the Board of Aldermen exercising a broad power under the city charter, may also be recalled.

\footnotetext{
${ }^{22}$ For a collection of the New York statutes, consult Handler, The Constitutionality of Investigations by the Federal Trade Commission: II (1928) 28 CoL. L. REv. 905,928 n. 106. For a collection of federal statutes conferring inquisitional power on officials, boards, commissions, etc., consult ibid. 925 et seq.

The great variety of investigating agencies brought to bear on the situation known as the "milk graft scandal" in New York a few years ago may be recalled. Investigations were carried on by the Health Commissioner, the Grand Jury, Judge Kelby, and Judge Tompkins sitting as a committing magistrate in a John Doe proceeding, which was severely criticized by the district attorney. Consult the New York Times Index for the period from Jan. 1926-Dec. 1927.

${ }^{23}$ See Landis, Congressional Investigations (1926) 40 HARv. L. REv. 153. As for the frequently exercised Congressional power of investigation, the all-embracing character of "legislative purpose" discourages any attempt to set limits to its scope.
} 
Doctrine, of course, distinguishes between investigations "criminal in character" and those "non-criminal in charncter," all of those discussed in the present section falling within the latter group. It is a distinction, however, which rests on no necessary difference in the subject matter of inquiry, nor again on the uses to which the evidence so extracted may eventually be put. Although any one of these investigating bodies may be forced to meet a jurisdictional attack by exhibiting the appropriate purpose other than criminal prosecution, within their respective scopes-and it is difficult to imagine any act of official misconduct, or even of private misconduct where it has a bearing on official, which does not fall within at least one of thesethey quite naturally serve to uncover considerable crime, and lead not infrequently to the lodging of criminal accusations. The practice of turning over evidence obtained in one of these investigations to the prosecuting attorney or grand jury, and such dual appointments as that of Max Steuer to act simultaneously as a Moreland Act commissioner (non-criminal in theory) and a Special Assistant Attorney General, in the investigation of the Bank of United States closing, are examples in point.

The function of investigating crime thus comes to be distributed amongst a number of variously adapted inquisitorinl bodies-the distribution depending, of course, on the range of those available in the particular locality. Grand juries and "one man grand juries" are distinguished from the rest by their general availability or non-specialized character, since they are the only agencies empowered to inquiry generally, armed with subpoena power, into criminal transactions of every type.

II

\section{Restraints on the Initiation of Investigation}

The possibilities of abuse inherent in general inquisitorial power have naturally suggested the desirability of curbing its arbitrary exercise. The situation with reference to grand juries as understood in the early days of this country, however, was set forth as follows by James Wilson, one of the first justices to sit on the Supreme Court:

"It has been alleged, that grand juries are confined, in their inquiries, to the bills offered to them, to the crimes given them in charge, and to the evidence brought before them by the prosecutor. But these conceptions are much too contracted; they present but a very imperfect and unsatisfactory view of the duty required from grand jurors, and of the trust reposed in them. 
"The oath of a grand juryman-and his oath is the commission, under which he acts-assigns no limits, except those marked by diligence itself, to the course of his inquiries; why, then, should it be circumscribed by more contracted boundaries? Shall diligent inquiry be enjoined? And shall the means and opportunities of inquiries be prohibited or restrained?" 24

In Pennsylvania, however, restriction was favored.: In that state, to this day, a grand jury may not proceed to investigate in the absence of a charge by the court concerning the particular matter in question. ${ }^{26}$ Should the jury desire to inquire into some matter not previously placed in their charge, they must present the need to the court, as of their own knowledge.st But whether or not the knowledge of but a few of the jurors suffices is not made clear. ${ }^{28}$ In any case, after a proper presentment, the court may transform the grand jury into an inquisitorial body by a "charge" specifying the condition to be exposed, or denoting the nature of the offenses to be investigated. Subpoenas may then issue, and investigation proceed.

242 WILSON'S WoRKS (Andrews' ed. 1896) 213-214. For further information on the early practice, consult U. S. v. Thompkins, Fed. Cas. 16, 483 (C.C.D.C. 1812).

${ }^{25}$ Matter of the Communication of the Grand Jury (Floyd \& Carpenter's Case) 5 PA. L. J. 55, 3 Clark 188 (Quarter Sessions Phila. 1845); REForT of the Crintes Survey Commitree, Law Assoclation of Phimadelphin (1926) 96; 1 Wharton, Criminal LaW (5th ed. 1861) §§ 458, 459; Bell, The Several Modes of Instituting Criminal Proccedings in Pmonsylinnin, 13 PA. Dist. REP. 815, 827 (1904); see MicCullough v. Comm., 67 Pa. 30, 33 (1870) ; Comm. ex rel. Jack v. Crans, 2 Pa. L. J. Rep. 172, 181 (1844).

26 Matter of Alleged Extortion Cases, 29 Pa. Co. Ct. 538 (1901); Comm. т. Klein, 40 Pa. Super. Ct. 352 (1909); see Comm. v. Zortman, $33 \mathrm{~Pa}$. Co. Ct. 219, 223 (1906); Comm. ex rel. Phillips v. Norris, 15 Luzerive LEG. REG. 409, 413 (1911).

For illustrations of the procedural steps and of the charges, consult Comm. v. Kenehan, 12 Dist. \& Co. Rep. 585, 30 Lacka, Jur. 58 (1929); Mratter of Grand Jury, 65 Pitrsburgh LEg. J. 521 (1917); Charge to the Grand Jury, 5 Dist. Rep. 130 (1895); authorities cited in note 25 supra.

It is said that such charges may be given only as to "matters affecting the community generally"-a further limitation of indefinite scope. The whole Pennsylvania procedure is one of exception added to exception to the general rule denying the grand jury any independent power of investigation. It is hoped to consider the cases in greater detail in a forthcoming article on The Grand Jury in Pennsylvania.

${ }^{27}$ At this stage the jury may not subpoena witnesses. Comm. v. Green, 126 Pa. 531, 17 Atl. 878 (1889); see Comm. v. Dietrich, 7 Pa. Super. Ct. $515,520(1898)$.

This "presentment" is carefully defined, as the notice taken by a grand jury of an offense from its own knowledge and observation. See Bell, supra, note 25, at 826; Grand Jury v. Public Press, 4 Brewster 313, 317 (Pa. 1869); Comm. v. Green, 126 Pa. 531, 537, 17 Atl. 878, 879 (1899).

${ }^{28}$ It has been said that at least twelve members should each have personal knowledge of the crime in question. Matter of Butler Grand Jury, $28 \mathrm{~Pa}$. 
The question of restrictions was extensively considered by the New York Code Commissioners in 1849. While advocating a tremendous limitation on the indicting powers of the juries, they were not, however, persuaded to erect the restrictions on investigation found in Pennsylvania. ${ }^{29}$ And in this code there accordingly appears no preliminary requirement of a charge. This attitude has prevailed generally throughout the United States. ${ }^{30}$

An inquisitorial magistrate or prosecutor is likewise free from restraint in the initiation of an investigation, with the additional advantage of not having to wait, as in the rural counties, for the impanelling of a grand jury. As for the non-criminal agencies, they are more difficult to set in motion. A legislative committee must be voted, a Moreland Act Commissioner appointed. But some are free, like the Commissioner of Accounts or the head of a state department in New York, to initiate inquiry of their own motion.

\section{Resources and Equipment}

Granted the inquisitorial power and freedom to proceed, various practical considerations begin to arise. From the outset investigation depends on clues which may be followed up. Where and how are these to be obtained? Expert assistance is apt to be needed, sometimes a large organization of assistant counsel, accountants and trained investigators. Ample funds and the possibility of spending considerable time may be required.

How are grand juries situated in these regards? They may not, in the absence of most unusual statutory provision, retain their own counsel, accountants or detectives. ${ }^{81}$ Their budgets cover no more than the picayune fees of jurors and witnesses. The jurors themselves are laymen, presumably unskilled in investigation, and devoting but a small part of their time to the task at hand. Superficially, they would appear quite devoid of resources, forced to fall back on their own knowledge and such complaints as might voluntarily reach their ears.

Such was indeed the position of the primitive grand inquest in the days antedating the institution of public prosecutors and even of the subpoena power. For the rural communities of early England it was an arrangement probably by no menns

Co. Ct. 83, 87 (1903) ; cf. Charge to Grand Jury, 5 Pa. Dist. Rep. 130 (1895).

${ }^{29}$ Fourth Report of the New York Commissioners on Practice AND Pleadings (Code of Criminal Procedure) (1849) xxxvii.

${ }^{30} \mathrm{~A}$ detailed study of the authorities on this point will be presented in

a forthcoming article on The Development of Grand Jurics.

31 (1922) 7 Mins. L. Rev. 59; Note (1923) 26 A. L. R. 605; (1928) 12

MINN. L. REv. 761. 
unworkable. There was common knowledge, and the gentlemen of the inquest were genuinely representative. Quite a different institution is the grand jury of American jurisdictions, elaborated in the draft code of 1849 and ensuing state codes of criminal procedure. Not only had the respective rooles of jurors and witnesses in the modern sense become long since differentiated, but, still more to the point, prosecution had become public. An elaborate organization of prosecuting attorneys and police departments has grown up around the grand juries.

Prominent in grand jury legislation are provisions contemplating the interdependence of these agencies.32 For expert aid the juries are to depend on the organization of the prosecutors, and through them on the resources of departments of police. The district attorney thus stands as counsel and moving spirit of the juries, appearing before them to examine witnesses and in fact conduct the investigation. In some jurisdictions the power to issue grand jury subpoenas is for convenience reposed in him. ${ }^{33}$ In this light the jurors are relegated to the position of lay referees, but referees clothed with the inquisitorial power which the prosecutor does not legally possess. In the normal situation a grand jury is thus designed and in fact operates as a prosecutor's instrument-a highly effective instrument for conducting an investigation ex parte and in secret. It provides him in addition with a shield, with moral support.

It follows that grand jury evaluation resting indiscriminately on criteria of independent initiative involves misconception of the design of our procedural scheme. To carry the burdens of expert investigators and legal counsel, the juries are in no sense equipped and scarcely encouraged. For the uncovering of clues and the driving along of investigation, reliance is placed, under our codes, on the prosecutors and police. Civic organizations and private individuals also figure prominently in widespread investigations. New York City, for example, has had its Parlhurst and its Citizens' Union, Chicago its Crime Commission and "Secret Six."

32 For example, MITCH. CoMrp. Laws (1929) \$ 17234-17236; MTONT. RET. Code (Choate, 1921) \$11829; Neb. CoßrP. STat. (1929) § 1408; NEv. Cosrr. Laws (Hillyer, 1929) § 10828; N. M. STat. ANN. (Courtright, 1929) c. 78, par. 228.

The practice under such a statute led the Colorado court to suppose that the district attorney had been entitled to be present and examine all witnesses regardless of the vishes of the jurors even at common law. People ex rel. Dist. Atty. v. Dist. Ct., 75 Colo. 412, 225 Pac. 829 (1924).

${ }^{33}$ For example: Kan. Rev. Stat. ANN. (1923) c. 62, \$ 916; Mícr. Co:rr. LawS (1929) \$ 17235; Neb. CoMrp. Stat. (1929) c. 29, par. 1409.

Some statutes provide that the grand jury may issue subpoenas. MONT. REv. CODE (Choate, 1921) §12179 (2) ; N. D. CoMrp. LAWS ANN. (1913) $\S 11025$. Tex. Rev. Code Crim. Proc. (Vernon, 1928) art. 382, confers the power on the foreman. 
But the normal picture just sketched must not completely obscure the potential independence of the jurors, on occasion asserted, particularly in exposures of local political corruption. To recall an instance, exposure of the Minneapolis system of graft under Mayor Ames' administration was forced through by the foreman of a grand jury. ${ }^{34}$ There is nothing to prevent the jurors, should they feel so inclined, from taking the reins in their own hands and launching an investigation. Should the prosecutor prove un-cooperative or actually hostile, they may exclude him from the room and proceed independently. ${ }^{35}$ Should he refuse to issue subpoenas or to draft desired bills of indictment, the court may order him to do their bidding, or supplant him with a special prosecuting attorney. ${ }^{26}$

For purposes of investigating into a particular incident a regular grand jury may be sufficiently equipped to proceed independently. But where a general investigation is contemplated, considerable time is required. A regular grand jury in Now York City, for example, devotes to its work but five mornings a week, of two hours each, for one month. And most of this time is necessarily occupied with routine. But special grand juries may be impanelled to conduct investigations, while the regulars carry on with the ordinary work of passing on bills of indictment, and may be continued over from month to month, to carry on a lengthy investigation. ${ }^{37}$ Thus one in Philadelphia was continued over successively during a period of seven months, while inquiring into the police department and local racketeoring. ${ }^{38}$ In New York City, both federal and state juries aro similarly from time to time continued over.

The lack of funds and expert assistance is, however, a serious obstacle in the case of a grand jury proceeding independently in a matter of considerable scope. Inquiry into complicated matters of public interest requires, moreover, considerable slkill. So it is that within their scope, the non-criminal agencies are apt to be more effective. ${ }^{30}$ Particularly is this the case where a whole system of organized corruption is to be exposed. The appropriations for the Hofstadter Committee run into the hun-

342 Lincoln Stefrens, Autobiography (1931) 377-379.

35-Matter of the District Attorney's Relations to the Grand Jury, $14 \mathrm{~N}$. Y. Cr. 431 (1900). Contra: People ex rel. Dist. Att'y v. Dist. Ct., supra note 32.

${ }^{36}$ For an instance where the attorney-general refused to procoed with a case before the grand jury, thereby leading the court to appoint a special prosecutor, consult N. Y. Times, Jan. 24, 1932, III, at 6.

${ }^{37}$ See Special Grand Juries in Illinois (1931) 22 J. Crim. L. 163.

38 Spectal Presentments of the Grand Jurx, Aug. Sessions, 1928, Court of Oyer and Terminer and Quarter Sessions of the Peace ror The City and County of Phila.

${ }^{30}$ Medalie, op. cit. supra note 13 , at 7 . 
dreds of thousands. It is served by a whole corps of assistant counsel, accountants, and trained investigators. The same was true of the investigation by the two Moreland Act Commissioners into the Queens Sewer Scandal of the Connolly régime. Such agencies are coming, more and more, to supplant grand juries in this field.

\section{Opportunity for Obstructive Tactics}

Prominent among the criteria of inquisitorial efficiency is the relative vulnerability of any particular agency to obstructive tactics of various kinds. The various non-criminal investigating agencies are, for example, particularly susceptible to jurisdictional attacks. Exercising their powers by virtue of particular statutes or resolutions, and within the limits of the respective legislative, administrative, or executive purposes upon which their validity depends, such bodies are constantly open to questions of constitutional scope and statutory construction. ${ }^{48}$ Witnesses may raise such objections, and, whether they be well grounded or not, considerable time and expense are consumed in bringing them to final test. The inquiry by the Hofstadter Committee has already involved an extra session of the New York legislature to patch up its statutory powers, and sundry appeals by the obstreperous with attendant stays. The first inquiry into the Queens Sewer Scandal by a Moreland Act Commissioner in New York was, after the expenditure of considerable time and money by the investigators, set at nought by a successful jurisdictional attack. New legislation had to be pas-

10 People ex rel. Webster v. Van Tassel, 17 N. Y. Supp. 938 (Co. Ct. 1892) (committee of common council); MIatter of Superintendent of the Poor, 6 App. Div. 144, 39 N. Y. Supp. 878 (2d Dep't 1896) (committee of supervisors); Matter of Nicosia, 180 App. Div. 427, 167 N. Y. Supp. 912, (1st Dep't 1917) (com'r of agriculture); Matter of MTendel, 162 App. Div. 371 , 147 N. Y. Supp. 603 (1st Dep't 1914), aff'd., 214 N. Y. 46, 108 N. E. 94 (1915) (transit commission); People v. American Ice Co., 120 App. Div. 234, 104 N. Y. Supp. 858 (1st Dep't 1907) (attorney-general under Ant:Monopoly Act) ; Matter of Rice, 129 Misc. 693, 228 N. Y. Supp. 851 (Sup. Ct. 1927) (attorney-general under Blue Sky law); Matter of Union Banl;, 204 N. Y. 313, 97 N. E. 737 (1912) (superintendent of banks); Mitchell r. Cropsey, 177 App. Div. 663, 164 N. Y. Supp. 336 (2d Dep't 1917) (Justice under Greater N. Y. City Charter $\$ 1534$ ) ; Matter of Foster, 139 App. Div. 769,124 N. Y. Supp. 667 (2d Dep't 1910) (commissioner of accounts); see Matter of Hirshfield v. Craig, 239 N. Y. $98,113,145$ N. E. 816,820 (1924); People ex rel. Sabold v. Webb, 23 N. Y. St. Rep. 324, 5 N. Y. Supp. 855, (Sup. Ct. 1889) (legislative committee); cf. MIatter of Barnes, 204 N. Y. 108, 97 N. E. 508 (1912); cf., also, The Hague cases, 103 N. J. Eq. 505, 143 Atl. 836 (1928); 104 N. J. Eq. 31, 144 Atl. 546 (1929); 104 ‥ J. Eq. 369, 145 Atl. 618 (1929) ; 105 N. J. Eq. 134, 147 Atl. 220 (1029); 9 N. J. Eq. 89, 150 Atl. 322 (1930). 
sed before the inquiry could go on, under conduct of a judge, and in secret session. 42

A grand jury, however, encounters practically none of these obstructions. Since it is charged with inquiry into all crimes committed in the jurisdiction, questions as to the scope permitted its inquiry do not tend to arise." A witness need be apprised of no "case" or "charge," 42 and the fruitlessness of quibbles as to relevancy discourages objections on that ground. ${ }^{43}$ Nor is a witness in other respects entitled to set limits to the investigation. As held in Blair v. United States, ${ }^{44}$ he may not contest the validity of a statute creating the crime under inquiry, nor may he challenge the authority and jurisdiction of the grand jury, provided it has "a de facto existence and organization." There are also practical difficulties in the way of raising objections. A witness is unattended by counsel. The little that appears on the face of a noncommittal subpoena is all that he is entitled to know concerning the aims and purposes of the inquiry. Hearings are secret, and proceedings are presumed to be regular, with practically no avenue open to the recalcitrant one for securing information. This unquestioned breadth of inquisitorial scope affords a calm and uninterrupted inquiry in striking contrast to the hurly-burly of a legislative investigation.45

Perjured and evasive testimony constitute still another form of obstructive tactics, suggesting brief consideration of the snnctions available against each. For the confinement of an inquiry, in theory, to some limited subject matter or purpose, mny restrict its progress indirectly by weakening the perjury sanction on the score of materiality, as well as directly by narrowing the field of the relevant concerning which answers may be compelled. To such limitations the non-criminal agencies are peculiarly subject. ${ }^{46}$

${ }^{41}$ See Matter of Connolly v. Scudder, 222 App. Div. 604, 605, 227 N. Y. Supp. 47, (2d Dep't 1928) ; Matter of Richardson, 247 N. Y. 401, 160 N. E. 655 (1928).

42 Matter of Black, 47 F. (2d) 542 (C. C. A. 2d, 1931); Hale v. Honkel, 201 U. S. 43, 26 Sup. Ct. 370 (1906); Note (1906) 6 CoL. L. REv. 347; Wilson v. U. S., 221 U. S. 361, 31 Sup. Ct. 538 (1911); see Matter of Naltional Window Glass Workers, 287 Fed. 219, 221-2 (N. D. Ohio, 1922).

43 Ex parte Butt, 78 Ark. 262, 93 S. W. 992 (1906).

44250 U. S. 273, 39 Sup. Ct. 468 (1919).

${ }^{45}$ Given a suitable statute, an inquisitorial magistrate or prosecutor should be similarly untrammelled.

${ }^{46}$ People v. Hebberd, 96 Misc. 617, 162 N. Y. Supp. 80 (Sup. Ct. 1016).

In Commonwealth v. Ransdall, $153 \mathrm{Ky} .334$, $155 \mathrm{~S}$. W. 1117 (1913), an attempt on the part of the state legislature to free a special investigntivo agency from the limitations of the element of materiality involved in porjury is discussed. But in a later case, Mitchell v. Comm., $237 \mathrm{Ky} .849,36$ S. W. (2d) 649 (1931), the same court indicates that a requirement of relevancy will still obtain. 
The rôle of the "materiality" requirement in prosecutions for perjury before a grand jury-or for that matter, before any body with comparably broad scope of inquiry-is inevitably one of extreme flexibility. Lacking even a definite charge to afford points of reference, such an issue with reference to the objects of a John Doe proceeding affords opportunity for considerable judicial control of inquisitorial scope. ${ }^{47}$ Since grand juries are not impanelled for mere groundless snooping, a question whether a witness knows of the commission of any crimes, may well be considered immaterial by a court unable to find the "point in question." ${ }_{48}$ But beyond that, guiding notions as to the "matter at issue," invoked to premise opinions leading one way or the other, would seem to denote pretty much what one may choose. Not infrequently a decision on materiality is accompanied by no expressed standard.93 In favor of untrammelled inquiry, the opinion in Carroll v. United States stands preeminent:

"Its investigation and full duty is not performed unless and until every clue has been run down -and all witnesses searched for and examined in every proper way to find if a crime has been committed, and to charge the proper person with the commission thereof. Its investigation proceeds step by step. A false statement by a witness in any of the steps, though not relevant in an essential sense to the ultimate issues pending before the grand jury, may be material, in that it tends to influence or impede the course of the investigation." 50

Where the summary power of contempt is invoked against falsehoods amounting to obvious obstructionism, no issues as to materiality need necessarily arise. ${ }^{51}$ The gist of the contempt is the insulting or frivolous quality of the objectionable answers. The range of this summary method should not-loose decisions to the contrary-comprehend each and every instance of false-

17 Amongst cases allowing a wide investigative range, consult State $v$. Wakefield, 73 MIo. 549 (1881); State v. Turley, 153 Ind. 345,55 N. E. 30 (1899); State v. Ackerman, 214 Mo. 325, 113 S. W. 1087; 22 L. R. A. (N. S.) 1192 (1908) ; People v. Howland, 63 Colo. 414, 167 Pac. 961 (1917); State v. Ruddy, 287 Mio. 52, 228 S. W. 760 (1921). For a narrower view, see People v. Morrison, 98 Misc. 555, 164 N. Y. Supp. 712 (Gen. Sess. 1917); Clayton v. U. S., 284 Fed. 537 (C. C. A. 4th, 1922).

48 State v. IIcCormick, 52 Ind. 169 (1875). But where a grand jury is expressly allowed to call and question any witness as to whether he lnows of any crime, the perjury sanction is available. State v. Terry, 30 Mro. 368 (1860); Wofford v. State, 21 Ala. App. 521, 109 So. 886 (1926).

49 For example, Brzezinski v. U. S., 198 Fed. 65 (C. C. A. 2d, 1912); Lewis v. State, 78 Ark. 567, 94 S. W. 613 (1906); State v. Sweeten, 83 N. J. I. 369, 85 Atl. 311 (1912).

so 16 F. (2d) 951, 953 (C. C. A. 2d, 1927) ; Note (1927) 40 HARv. L. REv. 780.

51 See People v. Freeman, 256 Ill. App. 233 (1930). 
hood stirring inquisitorial impatience. Nor may it properly be employed as a thumbscrew for third-degreeing a witness into telling any story desired by the inquisitors..$^{52}$ Its proper function is simply to exert pressure on a witness blocking an inquiry, by falsehoods patent, or evasions as to matters obviously within his own knowledge. Resort to such tactics will justify commitment of the recalcitrant one to jail until, in the words of Judge Learned Hand, "he may appear . . . and see whether" he can tell a story which is not so obviously a mere sham." os The development of this summary method for controlling the contumacious is identified, however, almost exclusively with proceedings of trial courts. For its extension to grand jury proceedings, one must look to the southern district of the second federal circuit in New York. ${ }^{54}$ No similar extension to proceedings before non-criminal investigating bodies is noticeable, and might well encounter considerable judicial reluctance. For they may not, like the grand jury, be regarded as "arms of the court," and the contempt power is charily granted.

\section{Compelling Attendance and Testimony of Suspects}

A feature of the John Doe form of inquisitorial proceedingsunlike those following the lodging of specific charges of crimeis the possibility of calling all persons with knowledge, whether they be suspects or not. Were this not permissible, in general, investigation would be seriously blocked. But suppose the extreme case, where a person ultimately to be indicted is recognized as such from the start. Were one to proceed before a magistrate by complaint against such a person, he would then be entitled to refuse to answer all questions. He there has his privilege, just as on trial..$^{55}$ But under the John Doe form of inquiry no charge need be laid against him. As a matter of form he is not yet a party, though in fact the proceeding may well be aimed at him from the start. Construction of the privilege against self-incrimination here bears directly on inquisitorial scope.

The treatment of this problem, in connection with grand jury proceedings, exhibits a variety of attitudes, consonant with the increasingly controversial character of the party's privilege as a whole. Some courts refuse to look through the veil of the John Doe form at all. ${ }^{56}$ Feeling is also expressed that the wit-

52 See Nelles, The Summary Power to Punish for Contempt (1031) 31 CoL. L. Rev. 956, 969.

${ }^{53}$ U. S. v. Appel, 211 Fed. 495, 497 (D. C. S. D. N. Y. 1913).

5 Loubriel v. U. S., 9 F. (2d). 807 (C. C. A. 2d, 1926) ; U. S. v. Dachis, 36 F. (2d) 601 (S. D. N. Y. 1929); O'Connell v. U. S., 40 F. (2d) 201 (C. C. A. $2 \mathrm{~d}, 1930$ ).

55 4 WIGMORE, Evidence (2d ed. 1923) § 2260.

ธo U. S. v. Kimball, 117 Fed. 156, (C. C. S. D. N. Y. 1902) ; Pick v. State, 
ness' privilege of refusing to answer specific incriminating questions should suffice.57 Many courts, on the other hand, prefer a less forthright stand. A privilege against being called in a proceeding "in fact aimed against one" is apt to be conceded in principle, though often astutely avoided in the particular case. ${ }^{53}$ For example, the objection was not raised correctly, 50 or the error was not prejudicial, ${ }^{, 0}$ or to reverse a conviction would only mean the circuity of a proper re-indictment. ${ }^{\circ}$ But the privilege lurks in the bacliground, available where abuse is strongly felt. ${ }^{62}$

The same problem arises in proceedings before magistrates with inquisitorial powers, as evidenced by an opinion by the Attorney General of South Dakota in 1926, warning prosecutors that the Johin Doe form of complaint should not be used to cover the calling of suspects against whom proceedings were aimed from the start. ${ }^{63}$ The courts in that state took a similar view, although pointing out that it was for the aggrieved one to prove that a given proceeding was in fact aimed at him. The opposing attitude, to the effect that a privilege against answering specific questions is enough, is found in a decision by the Connecticut court. ${ }^{\mathrm{E}}$

In proceedings before a non-criminal inquisitorial body, however, no similar objection to the calling of suspects obtains. A proceeding by a Moreland Act Commissioner, such as that involved in Matter of Phillips, ${ }^{610}$ may indeed be aimed quite directly at a witness, but the purpose is non-penal-the removal of an allegedly incompetent official. The question of privilege arises, however, where the transcript of testimony is handed orer to the grand jury or, in an information state, to the committing

143 Md. 192, 121 Atl. 918 (1923); People v. Lauder, S2 Mich. 109, 46 N. W. 956 (1890).

57 State v. Comer, 157 Ind. 611, 62 N. E. 452 (1902).

ss People v. Page, 116 Cal. 386, 48 Pac. 326 (1897); Radinslyy v. People, 66 Colo. 179, 180 Pac. 88 (1919); Terr v. Torres, 16 N. MI. 615, 121 Pae. 27 (1911).

s9 State v. Anderson, 10 Ore. 448 (1882).

${ }^{60}$ State v. Donelon, 45 La. Ann. 745 (1S93).

61 See Lindsey จ. State, 69 Ohio St. 215, 224, 69 N. E. 126, 129 (1903).

$\approx 2$ People v. Gillette, 126 App. Div. 665, 111 N. Y. Supp. 183 (1st Dep't 1908) ; People v. Bermel, 71 Misc. 356. 128 N. Y. Supp. 524 (Sup. Ct. 1911); State v. Froiseth, 16 MIinn. 296 (1871).

$\therefore$ OP. ATT'Y GEN. S. D. (1926) 146. See also Matter of Johnson, 27 S. D. 386, 131 N. W. 453 (1911); State v. Daniels, supra note 14.

cs State v. Smith, 228 N. W. 240 (S. D. 1929).

45 See McCarthy v. Clancy, supra note 14, at 490, 148 Atl. at $55 \pi$.

is 143 App. Div. 522, 128 N. Y. Supp. 482 (2d Dep't 1911). In a proceeding looking to his removal from the office of borough president, respondent, then under indictment for offenses connected with the subject matter of the present investigations, was subpoenaed. His application for an order vacating the subpoena was unsuccessful on appeal. 
magistrate. In State v. Rixon ${ }^{\circ r}$ an indictment was quashed, where the grand jury had had before it a transcript of testimony given by the accused, in an investigation by the fire marshall, wherein the (subsequently) accused had been subpoenaed.

\section{Power to Take Action on the Findings}

Since the object of successful investigation is to induce action of one kind or another, the possibilities open to any given body are of considerable concern. If the prime objective is an exposure of corrupt conditions, for example, the body conducting the proceeding should be in a position to achieve publicity. Where it is to bring about prosecutions, a fairly direct connection between the investigators and formal criminal accusing agencies is desirable.

For the purpose of initiating prosecution, a grand jury is, of course, in the most favorable position possible. But one question arises: Is it to be permitted to indict at once, or only after bindover by a committing magistrate? The New York Code Commissioners, in 1849, strongly opposed the current practice of permitting indictment without preliminary bindover, feeling that so unrestricted a power of accusation was fraught with danger, in the form of indictments based on little or no evidence, and on charges which the accused might well have explained away if afforded an opportunity to do so before a committing magistrate. ${ }^{68}$ It was further urged in favor of the compulsory preliminary examination: "A responsible accuser is presented, to whom he may look for redress, if the accusation be malicious or unfounded; but when he is accused by the grand jury, this protection is denied him, and he is dragged before the bar of justice, to answer a charge possibly as false in its substance, as it may be malicious in the motive by which it is prompted." "on But this 'restriction has not generally found its way into the codes and practice of our jurisdictions. Here and there a statute requires the preliminary examination, but in the same jurisdictions alternative modes of proceeding without such examination exist. ${ }^{70}$ Hence, while always permissible and quite usual, proceeding by way of bindover is not essential.

A magistrate conducting a John Doe inquiry is likewise in a position to take direct action, in the form of binding the accused over for action by the grand jury or prosecutor. The non-

o7 180 Minn. 573, 231 N. W. 217, 68 A. L. R. 1501 (1930); (1030) 15 Minn. L. Rev. 344; cf. State v. Lloyd, 152 Wis. 24, 139 N. W. 514 (1013), Ann. Cas. 1914C., 418.

68 FoURTh REPORT, supra note 29 , at xxxvii.

69 Ibid. xxxviii.

70 The situations in Georgia, Pennsylvania and Tennessee will bo considered in detail in other articles. 
criminal investigating bodies are not, however, so happily situated, as suggested by the recent complaint of counsel for the Hofstadter legislative committee in New York: "All we can do here is adduce the facts. If the other agencies that are charged with the duties of enforcement will not act, how can we act?" "71 A solution for this predicament, where feasible, has been the type of dual appointment already referred to in another connection. Samuel Untermyer, for example, while counsel for the Lockwood Housing Investigating Committee of the legislature in New York, had himself appointed Special Deputy Attorney General and also Special Deputy District Attorney. As such he secured hundreds of indictments. ${ }^{72}$ Even though this be done, however, it is still necessary for a grand jury to rehear the evidence in a state where prosecution by indictment has not been abolished..$^{33}$

Where the primary objective is exposure of a general condition or official misconduct not quite amounting to crime, a grand jury is in a less favorable position. Grand jury proceedings are required to be secret, and disclosure of testimony there given is, in general, forbidden. From time to time, in consequence, a jury makes a "report." These documents may contain only comments on the state of the region, or impersonal broadsides against a condition, interesting chiefly as news. But when they attack an official or group, redress is apt to be sought. For while on public record, and thence into the newspapers, unlike indictments they cannot be met. Although unexpunged, they call for no trial. Will the court receive them? Has the subject aggrieved any remedy, either against the jurors reporting or a newspaper reprinting the report?

At the outset these reports must be distinguished from the presentments with which they have so often been confused, and in the legitimacy of which they have consequently tended to share. Presentments in strict sense are, just as indictments, specific charges of crime designating persons accused, but taken in first instance by a grand jury. They may be regarded simply as instructions for indictments, for the framing of the latter normally follows. ${ }^{74}$ However, since public prosecutors are, under

${ }^{71}$ N. Y. Herald Tribune, Dec. 12, 1931, at '8.

72 N. Y. Times, Dec. 13, 1931, I, at 19.

${ }^{73}$ See Tuttle, The Grand Jury System; Should It Bc Abolished or Strengthened? (1927) 5 THE PANEL 2, 3: "It should be possible for the judge or magistrate conducting such a public inquiry [referring to socalled John Doe proceedings] to do so in the presence of the grand jury sitting in open court. At the close of the inquiry, the court would instruct the grand jurors as to whether the evidence was in law sufficient to warrant the consideration as a basis for an indictment; and the grand jurors would then retire to consider their action."

"A definition of "presentment" is embodied in $\$ 270$ of the draft code 
our practice, available to the grand jury for the drawing up of bills of indictment, the presentment form is practically obsolete. Reports, on the other hand, are neither susceptible nor intended to serve as bases for indictments. The varying recoptions accorded reports suggest their separate consideration in two groups: first, those addressing themselves to a general condition; and second, those censuring particular persons.

To this day it is not uncommon for a grand jury, usually at the close of its term, to make a report concerning some condition in the county. In the seventeenth century these reports were apparently taken more seriously than at the present time. Considered the official exponent of county opinion, "the "Gentlemen of the Grand Jury' usually figured first" in petitions to Parliament, "whilst in their frequent presentments at the Assizes and Quarter Sessions they were perpetually drawing attention to grievances." 75 Then, as now, reports occasionally stirred up official irritation. American grand juries carried on the tradition. In colonial Virginia, for example:

"It appears to have been a common practice for grand juries gathered at the capital to express their opinions on things in general, and on the administration of the royal governor in particular. It was an advantage, therefore, for the Governor to have a group chosen who could be counted on to pass a laudatory resolution which he could modestly forward to the Board of Trade as an indication of public opinion. Talking matters into his own hands, Governor Nicholson (1698-1705) sent outside the capital for a foreman, and gave orders to the sheriff as to choosing or excluding other persons." 70

In making these reports the jurors were understood to act not as the representatives, but rather as a respectable collection of the people of the county. It was a practice founded on no law. In the words of an early Pennsylvania judge: "This authority is founded only on use and a presumed public convenience, and, when exercised discreetly, it may be attended with good effects." 77

But the prestige of grand jurors as formulators of county opinion was already on the wane during the eighteenth century,

of the New York Commissioners, supra note 29. Consult also 1 CinirTx's Criminal Law (1819) 110. In a few jurisdictions, by statute, "presentments" have taken on new meanings and aspects, particularly in Georgit, Louisiana, Oregon, Pennsylvania and Tennessee.

75 Sidney and Beatrice Webe, English Local Government from thip Revolution to the Municipal Corporations ACt: The Parisir and THi CoUNTY (1906) 455.

7's Scott, Criminal Law in Colonial, Virginia (1930) 70.

72 Observations on the Duty of a Grand Jury (1793), Addison's Roports (Pa. 2d ed. 1883) 70, 73. 
their reports exhibiting a diminishing frequency and gradual loss of reality. "By the end of the century they had come to be little more than sonorous generalities, loyal addresses, and declarations on national politics, usually 'high Tory' in character." "s When Edward Livingston drew up his Codes for Louisiana in the early nineteenth century, he felt the practice of making these reports to be unhappy, announcing in his Introductory Report that "so far as positive interdiction can go, this entrance to party spirit through the chamber of the grand jury has been closed." The New York Commissioners made no specific reference to the subject, either in their Code or Introduction, but the implications of both are in accord with Livingston's views. ${ }^{\text {so }}$ With the exception of the Louisiana Code, however, express statutory prohibitions of reports are lacking. Reports of the old type continue to appear, are generally receired without question, and may sometimes serve a useful purpose.

Reports censuring particular individuals raise new considerations. Granting that criticism of a public official-for such reports are usually directed at a local official-raises questions of public, or political, interest just as truly as a report concerning a condition, it is questionable whether grand juries may wisely be permitted this opportunity. Partaking in the public eye, as such reports well might, of the sanction and authority associated with grand jury accusation in the form of indictment, they would-carry a quite disproportionate weight. With the decreasingly representative character of grand juries and the increase of other organs for expression of censure of officeholders, the public interest factor has been felt to dwindle as against considerations leading to suppression of the reports.

First amongst the remedies available to aggrieved subjects of such reports are motions to expunge from the records. The development may be sketched from Matter of Gardiner ${ }^{\mathrm{B1}}$ arising out of an appearance before the grand jury in 1909 by that ardent reformer, the Rev. Charles H. Parkhurst, who urged them to make a "presentment" in regard to the general condition of the police force. The result was a report against the district attorney, charging him, so he claimed, "by imputation, with the commission of a crime, which it fails to specify," and he moved that it be stricken out. The court felt that "the grand jury should never, under cover of a presentment, present an in-

is SIDNEY AND BEATRICE WEBB, op. cit. supta note $\mathbf{7 5}$, at 456.

791 Livingston, Criminal Jurtsprudence (1873) 372.

80 Consider, for example, their insistence on a preliminary examination, and their general policy of curbing the arbitrariness of grand jury aceusation, discussed supra.

s1 31 Misc. 364, 64 N. Y. Supp. 760 (Gen. Sess. 1900). For a general note on the power to make reports, see (1923) 22 A. L. R. 1356, 1367. 
dividual in this manner" and accordingly ordered the report "set aside."

In 1905, however, in Matter of Jones, ${ }^{82}$ the county court refused to set aside a report censuring the board of supervisors, and was affirmed by the Appellate Division. Judge Jenks, writing the majority opinion, pointed to section 260 of the Code, charging grand juries to inquire into the condition and management of public prisons in the county, and the wilful and corrupt misconduct in office of public officials. Suggesting that these powers were conferred for some purpose, he concluded that reports were not always unwarranted. If rendered upon the exercise of these inquisitorial powers, though incidentally censuring this or that official, they need not be stricken out. He suggested, however, by way of dictum, that "if under the guise of a presentment, the grand jury simply accuse, thereby compelling the accused to stand mute, where the presentment would warrant indictment so that the accused might answer, the presentment may be expunged." An appeal from this order was dismissed, the Court of Appeals finding neither "an inherent right of $\Omega$ peal" nor statutory authority on which it might base jurisdiction, and adding: "Such a motion does not involve a legal right of an individual, but the right of the court itself to keep its own records free from matters of an immaterial or improper character." 83

More influential than the majority opinion of the Appellate Division in Matter of Jones, was the dissenting opinion of Judge Woodward. ${ }^{84}$ His view of the Code empowered grand juries only to indict or not indict; so-called "presentments" against individuals, affording no opportunity to be heard and defend, were not to be tolerated. What of the argument of Judge Jenks, that from section 260 may be inferred a power to make reports or so-called presentments? The statute is silent as to what grand juries shall do after making the investigations there required. As to condition and management of the public prisons, one might infer from this an authority to make general reports; but corrupt misconduct in office is always indictable, and in that instance at least, failing indictment, reports have no place. ${ }^{85}$ Lower New York courts have refused to follow the Jones case majority, in each instance granting the desired motion to expunge. ${ }^{80}$ In the

82101 App. Div. 55, 92 N. Y. Supp. 275 (2d Dep't 1905).

s3 Matter of Jones, 181 N. Y. 389, 74 N. E. 226 (1905).

st Supra note 82, at 59, 92 N. Y. Supp. at 277.

85 Medalie, op. cit. supra note 13. For similar construction of similar statutes, see Matter of Report of Grand Jury of Baltimore City, infra noto 88; Parsons v. Age Herald Pub. Co., infra note 96, at 446, 61 So. at 349: Rector v. Smith, infra note 95 , at 306 .

${ }^{80}$ Matter of Osborne, 68 Misc. 597, 125 N. Y. Supp. 313 (Sup. Ct. 1010). For comment on this case, see Medalie, op. cit. supra note 13, at 6. Seo also 
latest of these, Judge Heffernan found presentments abolished, for "unless the Court comes to his [the applicant's] aid, he is left without any remedy, except an appeal to the court of Mrrs. Grundy." st

This attitude has been reflected in recent appellate decisions of Maryland ${ }^{88}$ and Wisconsin, ${ }^{80}$ where refusals to expunge reports attacking public officials were reversed on appeal. The issue is viewed as one of power, truth or falsity being immaterial. With respect to a statute similar to section 260 in New York, and providing that the jury "shall make presentments of all offenses and omissions of any person in or relating to said institution" (the jail), the Maryland court indicated that reports would be proper "so long as they do not point out individuals as subjects of public criticism and opprobrium."

In the foregoing cases appeals were entertained, but suppose, as occurred in Matter of Jones, jurisdiction to review is denied. Mandamus also may fail, as in Missouri ${ }^{30}$ and Nevada, ${ }^{02}$ refusal to expunge being considered no mere ministerial act. In MIichigan, however, mandamus will issue without concern as to distinctions between "ministerial" and "judicial," nor as to whether there be other adequate modes of redress. ${ }^{32}$ The reports are unauthorized and reprehensible. That, in Michigan, appears to be enough.

A suit for libel may also be based on one of these reports, as in Bennett $v$. Stockwell, ${ }^{33}$ which involved the very report ordered expunged in one of the Michigan cases. To a plea of qualified privilege the court replied that, had any privilege attached, it would not have ordered the report expunged. Any showing of good faith and the like was relegated to the end of

Miatter of Funston, 133 Misc. 620, 233 N. Y. Supp. 81 (Sup. Ct. 1929); Miatter of Crosby, 126 Misc. 250, 213 N. Y. Supp. 86 (Sup. Ct. 1925); MIatter of Woodbury, 155 N. Y. Supp. 851 (Sup. Ct. 1915); Matter of Osboine, 68 Misc. 597, 125 N. Y. Supp. 313 (Sup. Ct. 1910); MIatter of Heffernan, 125 N. Y. Supp. 737 (County Ct. 1909).

87 Matter of Funston, supra note 86, at 623, 233 N. Y. Supp. at 82.

88 Matter of Report of Grand Jury of Baltimore City, 152 MId. 616, 137 Atl. 370 (1927).

89 Matter of Grand Jury Report, 235 N. W. 789 (Wis. 1931).

2n State ex rel. Lashly v. Wurdeman, 187 S. W. 257 (IIo. 1916).

91 State ex rel. Weber v. MicFadden, 46 Nev. 1, 205 Pac. 594 (1922).

92 Oakman v. Recorder of City of Detroit, 207 Mich. 15, 170 N. W. 346 (1919) (report by a "one man grand jury") ; Bennett v. Kalamazoo Circuit Judge, 183 Mich. 200, 150 N. W. 141 (1914), Ann. Cas. 1916E 223. In HIGH, ExTraordNARY LEGAL REMIEDIES (3d ed.1896) 196, the author comments on the exceptional scope given to the writ of mandamus in the jurisdiction of Michigan. See also State ex rel. Weber v. McFadden, supra note 91, at 7, 205 Pac. at 595.

93197 Mich. 50, 163 N. W. 482 (1917), L. R. A. 1917F 761, Ann. Cas. 1918E, 1196; (1918) 2 MINN. L. REv. 154. 
mitigating damages. ${ }^{24}$ Courts of other jurisdictions, however, while concurring as to the lack of power to make such reports in the first place, feel impelled to recognize a qualified privilege. ${ }^{.6}$

Where the action is against a newspaper republishing the report, the press is usually said to stand in the shoes of the jurors, and the few cases on the subject accord a qualified privilege.0 In Michigan, however, where the jurors enjoy no privilege whatsoever, it may be supposed that the press would be similarly defenceless. The qualified privilege view is most clearly expressed in the Alabama case of Parsons v. Age-Herald, Pub. Co., where the report censured a constable but expressly fell short of finding grounds for impeachment. While declaring the report un authorized, the court nevertheless took heed of the immemorial practice of making such reports, and suggested that these reports were within the spirit if not the letter of the privilege of fair comment in judicial proceedings, understood with the following reservations: "... (1) That libelous imputations in a grand jury's report upon private citizens, or upon public officers, not touching their fitness for office or their fidelity to the public service, or the propriety of their official acts, are not properly matters of public interest; (2) that the privilege does not attach at all until the report has been duly published by the grand jury itself in open court; and (3) that matters, the publication of which is forbidden by law, or by the order of the court as being improper for publication, are not to be regarded as privileged with respect to their publication by third persons." ${ }^{\circ r}$

Such is the reception accorded grand jury reports. Taken in

94 On the issue of good faith or malice it may be important to show how particular jurors acted in their deliberations, with reference to the roport. The trial court in Bennett v. Stockwell ruled that a statute [MicH. CoMp. LAWS (1897) §11887] precluded the admission of testimony by grand jurors as to proceedings in the grand jury room respecting the voting for, composition and publication of the alleged libel. On appeal, howover, it was held that the statute was not applicable to questions not proporly before the grand jury, i.e., reports of this character, and that consequently the testimony would be receivable.

${ }^{95}$ Rector v. Smith, 11 Iowa 302 (1860); Rich v. Eason, 180 S. W. 303 (Tex. Civ. App. 1915); (1916) 64 U. PA. L. Rev. 391; (1916) 16 CoL. L. Rev. 163.

In Coons v. State, 194 Ind. 580, 134 N. E. 194, 20 A. L. R. 908 (1922), a report upbraiding the presiding judge was treated as a direct contompt. The case is noted with approval in (1922) $70 \mathrm{U}$. PA. L. REv. 331.

ac Ferguson v. Houston Press, 1 S. W. (2d) 387 (Tex. Civ. App. 1927) i Parsons v. Age-Herald Pub. Co., 181 Ala. 439, 61 So. 345 (1913). In Poston v. Washington, Alexandria \& Mt. Vernon R. R. Co., 36 D. C. App. 359,32 L. R. A. (N. S.) 785 (1911), the court held, in reversing an order sustaining a demurrer to the complaint, that the report was not privileged as part of a judicial proceeding. Whether it would deny even a conditional privilege is not entirely clear.

${ }^{97}$ Supra note 96 , at 448,61 So. at $3 \underline{48}$. 
connection with the requirement that all proceedings by a grand jury be conducted in secret, and the prohibitions against any disclosure of what takes place in the grand jury room, it becomes clear that grand jury investigation is totally unsuited to siturtions calling for public exposure of whole systems of corruption more urgently than the prosecution of particular individuals. The non-criminal investigating agencies are not similarly hampered. A legislative committee, like the Hofstadter for example, may conduct public hearings. No requirement of secrecy is imposed, there is the privilege for fair comment, and full scope for the publicizing of findings and charges is consequently afforded.

\section{III}

From the foregoing review of investigating agencies with contrasting adaptabilities, it is clear that no single uniform scheme for allocating inquisitorial powers and responsibilities exists. In some jurisdictions grand juries are largely supplemented by specialized agencies for purposes of widespread inquiry into official misconduct, while in others the juries are primarily relied on. In some the juries have been supplanted for ordinary investigation into crime by magistrates and prosecutors of the "one man grand jury" type.

In other respects grand juries differ widely as one passes from rural to urban counties, from state to state, and from the states to the federal jurisdiction. With the pressure of business in New York City, where three or more juries are constantly in session in each county, one may contrast the situation in the upstate counties, where but two or three a year are impanelled. The very calibre of the juries themselves varies with differing modes of selection, and the institution of Grand Jurors' Associations, ${ }^{98}$ as in New York and a few other regions, alters the picture considerably for the better in this regard. The type of business handled by federal grand juries differs widely from that entrusted to those of the states. The former are concerned for the most part with crimes that may be considered at leisure; their field is broader than that of the state juries which are concerned in the main with suppressing violence.

Grand juries are differentiated on still another plane by variations in the local systems of which they are integral parts. The need for and activities of a grand jury may take on one aspect

98 These voluntary associations date from 1913, when the first was founded in New York County. Since then others have been organized for five other New York counties, two New Jersey Counties, Baltimore, Ilinois, and the Southern and Eastern Federal Districts of New York. As to the activities of these associations, see The PANel and The Feneral Junor, periodical publications of the New York County and Southern Federal District of New York associations. 
where magistrates' courts are centralized,,$^{00}$ and where prosecutors are of a relatively high grade, on full time and adequately equipped; but quite another where the magistrates are scattered justices of the peace, and where the prosecutors are on part time and without assistance. For a grand jury does not function in a vacuum. As an integral part of a system, a given jury will exert influence and be influenced in a manner largely dependent on the state of other agencies in the local process. Conclusions here in terms of "the grand jury" are accordingly out of the question. They could have no reference but to some imaginary institution, fashioned from the data of diverse localities, by an indiscriminate use of average and median. The issues controlling a choice between grand juries and inquisitorial magistrntes or prosecutors-i.e. whether a jury affords moral support or a demoralizing dissipation of responsibility, whether the merely occasional character of friction between jury and prosecutor indicates rubber-stamping or cooperation, and whether a jury constitutes an effective non-political agency for keeping tabs on the conduct of public officials or rather on irrelevancy injected into the process, too inexperienced and out of touch to exert an influence sufficient to justify their maintenance-can, therefore, be determined only with reference to a particular jurisdiction.

Little improvement in quality of process is to be anticipated from mere substitutions of other agencies for grand juries. Critics and crime surveys find shortcomings on the part of prosecutors and magistrates quite comparable to those attributed to the juries. ${ }^{100}$ In those jurisdictions where grand jury investigation has already fallen into complete disuse, attention may profitably center on the quality of the magistrates and prosecutor's relied upon. But in the federal jurisdictions and in the many states where grand juries are firmly entrenched, little prospect and no compelling reasons for their elimination appenr. The problem in these quarters is to raise the standard of grand jury investigation along the lines being marked out by the Grand Jurors' Associations.

89 Harley, Detroit's New Model Criminal Court (1920) 11 J. Crim. L. 398; Report OF The EFficiency Committee OF Kentucky ON THe Judictary OF Kentucky (1923); Corrigan, Centralization Of Magistratos' Courts In Manhattan (1928) 6 THE PANEL 1.

${ }^{100} \mathrm{As}$ to the magistrates' courts consult: Mrssouri Crime Survex (1026) 128, 156; Illinois Crime Survey (1929) 305-308; Molex; Our Criminat Courts (1930) c. 2; Report ON Criminal Procenure Of The National Commission For LaW ObServance ANd Enforcenent (1931) 11 at so\%.

As to prosecutors consult Missouri Crime SURvex, 131-157; ILLINols Crime Survex, 278-9; Moley, Politics ANd Criminal Prosecution (1929) 74; REPORT ON Prosecution, supra note 1 , at 14. 